\title{
Occupation and Gender Stereotypes in Primary School: The Case of the English Language Coursebooks in Greek Primary Schools
}

\author{
Vassiliki Teliousi ${ }^{1, *}$, Makrina Zafiri ${ }^{2}$, Vassiliki Pliogou ${ }^{1}$ \\ ${ }^{1}$ School of Education, Metropolitan College Thessaloniki, Greece \\ ${ }^{2}$ Foreign Language Office, Aristotle University of Thessaloniki, Greece \\ Received November 26, 2019; Revised February 25, 2020; Accepted March 12, 2020
}

Copyright $\mathrm{C} 2020$ by authors, all rights reserved. Authors agree that this article remains permanently open access under the terms of the Creative Commons Attribution License 4.0 International License

\begin{abstract}
This research refers to gender stereotypes, which exist in English language coursebooks in Greek primary schools and the possible influence these stereotypes may exert on the choice and development of an individual's career. After conducting a content analysis on the Primary School's English language coursebooks, the results prove the existence of gender stereotypes mainly in the $5^{\text {th }}$ and $6^{\text {th }}$ grade coursebooks. The references and pictures, which show male performing certain occupations obviously outnumber the ones depicting female occupations. Furthermore, in the coursebooks, there are stereotypical ideas such as: manual occupations which are ruled by men, while occupations which relate to education and care are performed by women. Moreover, an attempt was made to triangulate this research with semi-structured interviews, which were conducted to English language teachers. According to the English language teachers' experiences, the existence of gender stereotypes on occupation is evident in the English language coursebooks of the $4^{\text {th }}, 5^{\text {th }}$ and $6^{\text {th }}$ grades, but is minimal in the textbook of the $3^{\text {rd }}$ grade. To sum up, most of the teachers, who were interviewed claim that later in life, career choice is influenced by the stereotypes which exist in the $4^{\text {th }}, 5^{\text {th }}$ and $6^{\text {th }}$ grade coursebooks, but only to a limited extent. According to the teachers who were interviewed, the teaching methods and approaches, which are applied by the teachers and which concern the teaching of the coursebooks and the social and family background of the students are the main factors, which influence the student and which exert a strong impact on the student's career choice.
\end{abstract}

Keywords Gender Stereotypes, English Language Coursebooks, EFL Teaching, Career Choice, Male Occupations, Female Occupations

\section{Introduction}

Despite the progress of the Greek educational system through the past decades, gender stereotypes, which have affected all social walks of life for centuries, seem to be reproduced consciously or subconsciously, even today, in several facets of the Greek educational system [1]. Gender influences are instrumental in students' career choice [2]. Everyday school routine, along with the role of the teacher, constitutes a significant part of the student's social environment, and from as early as primary school the aforementioned seem to affect the school performance of students as well as the formation of their opinion on matters such as the choice of a job or an occupation. More particularly, school coursebooks contain gender stereotypes, which have a strong influence on the formation of their ideas and perceptions about the role of each gender in society and also lead students to specific choices and expectations [3]. Research shows that the gender gap which exists in the school environment has an impact on students' studies, career choices and occupations later on in life. This can be avoided if methods and practices for integrating gender equality in schools are applied, at an early stage, by teachers [4]. An overview to studies which exist worldwide on gender representations in the primary school coursebooks proves that gender stereotypes still exist, at least in coursebooks, and consequently, if we take into account the teachers' opinions, they are still evident in the daily school life of all students in Greece. Something which has not been researched, so far, is the possible influence of gender stereotypes on English primary school coursebooks in Greece which relate and influence the future occupation or career choice of Greek students. This constitutes the topic of this study.

The main purpose of the present study is to probe into the gender stereotypes which relate to occupations and 
will later influence the career choice of the students - who are attending primary school - through a qualitative analysis of the English language coursebooks which are used in Greece. More specifically, a content analysis will be conducted in the English language coursebooks of the $3^{\text {rd }}, 4^{\text {th }}, 5^{\text {th }}$ and $6^{\text {th }}$ grades of Greek primary schools.

The research questions which have been formulated and refer to each of the four English language coursebooks which are used in Greek primary schools are the following:

1) Are gender stereotypes detected in all the English Language coursebooks which are used in Greek primary schools?

2) How often do gender stereotypes, which relate to occupations, appear in the written texts of the English Language coursebooks which are used in Greek primary schools?

3) How often do gender stereotypes, which relate to occupations, appear in the illustrations of the English Language coursebooks which are used in Greek primary schools?

4) To what degree is the occupational choice of Greek primary school students influenced (later in their lives) by gender stereotypes which exist in English Language coursebooks?

The English language was first introduced in Greek schools in two stages. The first stage was the experimental stage between 1988-1992, while the second stage included the expansion of the English language to all the Greek schools nationwide (and that included Junior and Senior High Schools) during 1992-1995 [5]. More specifically in the school year 1987-1988, eighty primary schools included English language lessons in the $4^{\text {th }}$ grade at an experimental level. Since 1993 the English language has been taught for three hours per week in the $4^{\text {th }}$ grade of primary school. In 1993 (and onward) the English language was taught for six years, starting from the $4^{\text {th }}$ grade of primary school until the 3rd grade of junior high school as a 6-year foreign language program [5]. In the same year the second foreign language was introduced to all junior high schools of the country. Moreover, in 2003 with the educational reformation in Greece, the English language was introduced to the $3^{\text {rd }}$ grade of primary school for 3 hours per week [5].

A new decision which was made in the school year 2016-2017 which introduced the teaching of English as a foreign language in the first two grades of primary school as part of a program called 'English for Young Learners' (EYL). The idea of introducing English as a foreign language in the first two grades of primary school was based on research which was conducted between the years 2010-2014 by the National and Kapodistrian University of Athens in collaboration with a co-financed program called PEAP. The program emphasized upon the student-centered approach and was not based on a certain curriculum or book. Quite the contrary, the main objectives of the lessons were to teach English as a foreign language to grade one and grade two students of Greek primary schools through several activities which were chosen by the teacher [6]. The instruction materials for the aforementioned grades of primary school included songs, games, poems, short fairy tales, simple stories, cartoons and crafts.

\subsection{The Cross-Thematic Curriculum Framework (DEPPS)- Integrated Foreign Languages Curriculum (IFLC)}

According to the Cross-Thematic Curriculum Framework (DEPPS) for foreign language teaching, and more specifically for English language teaching, there are three major axes, literacy, multilingualism and multiculturalism. As far as literacy is concerned, the main objective is spoken and written language acquisition. The axis which probes into multilingualism refers to the utilization of other languages and cultures so that students can better understand the world and communicate efficiently in multilingual environments [7]. The third axis is that of multiculturalism and its main aim is to encourage students to utilize the different elements of a language and at the same time to respect and accept the 'other', the 'different' thus helping students to shape a multicultural consciousness [8].

In the Integrated Foreign Languages Curriculum (IFLC) which became the official curriculum in 2016, the teacher encounters the special objectives of foreign languages teaching, which were previously also described in the DEPPS, and the thematic units. In addition, lesson plans and indicative activities can also be found in the curriculum for every thematic unit for the $3^{\text {rd }}, 4^{\text {th }}, 5^{\text {th }}$ and $6^{\text {th }}$ grades of Greek primary schools according to the principles of literacy, multilingualism and multiculturalism (IFLC, Educational Institute, 2001). The last part of the curriculum includes suggestions on teaching methodologies and approaches, as well as techniques, so as to support the learning process [9].

\subsection{Stereotypes and Gender}

In modern societies the gender identity of a child is shaped by social institutions such as the family, the school or the social environment of the child [10]. The male identity is commonly defined by the occupation the male holds as well as his social status, while the female identity is usually determined by the role she plays in the family as a care giver [11]. According to this view, individuals of both genders are forced to adopt certain roles so that they can be accepted by the society in which they live [11]. Thus, stereotypes concerning gender roles eventually shape a person's stature or standing in a particular society. It is impressive to see that people are given qualities which they have never chosen, or which they may not even have but may determine their gender identity [12].

The general term stereotype (or stereotypes) is used to 
describe the simplified ideas and features which are attributed to a specific group of people. These features often have negative connotations which often justify the possible discrimination or racist behavior of the dominating social group towards the people who are considered to be in the minority [13]. It is believed that stereotypical ideas which are directed to these minorities are corrosive for both them and their social environment while, at the same time, they also limit their horizons and prospects in life [14].

On the other hand, gender stereotypes constitute the ideas that define the attitude which a society may have of the skills, the preferences and the social roles a male or a female should have or should 'play' (especially when considering the role each gender plays in a given society) when living in that particular society [15]. Gender stereotypes are also considered to be the characteristics that are attributed to people based on their gender [16]. These stereotypes are grounded in beliefs such as, for example, that males are physically stronger and thus more able to lead and take on responsibilities compared to females who usually have assistant roles, such as the role of the housewife and mother who is responsible for the upbringing of a child or is responsible for its education [17]. As Fiske states, the average woman is characterized as nice but unable, whereas an average man is skillful and nice [18].

\subsection{Gender Stereotypes, Textbooks and Education}

The formation of ideas and attitudes which concern gender roles usually begins at a very early stage of a child's life through the family environment in which the child lives and is reared through the beliefs the family may have concerning the two sexes [19]. The factors, which influence a child's opinion and idea, or ideas on what genders are, broaden when the child starts school. The students now interact with their peers, as well as with their teacher in a structured environment. The teacher's opinion concerning gender roles may affect their students' attitudes, ideas and performance directly or indirectly [12]. Since the teacher is the authority figure in the classroom, his or her opinion on the role that each gender plays in a given society may influence his or her students' attitudes towards gender roles and may even encourage them to adopt these attitudes for life [12]. After all, there is serious evidence that the teacher is able to exert a strong influence on his or her students, by stimulating or downgrading their behavior, selecting the teaching material from the proposed curriculum, ranging students according to the grades they receive, creating a positive or a negative classroom atmosphere and reinforcing the development of their mental capacities [20].

On the other hand, school textbooks, mainly in Greek primary schools, transmit social rules and norms which influence the behavior and the roles of the two genders. Amongst all the textbooks which are used in Greek primary schools, the ones with the strongest impact and influence on students' gender roles are the language and literature textbooks, as the student obtains ideas, on gender roles, through their texts and their illustrations [21].

\subsection{Gender Stereotypes and Occupation}

Nowadays, there is an intense effort made in order to eliminate gender stereotypes which concern occupations. Men and women now choose occupations that were supposed to be exclusively male or female. Nevertheless, there are several issues that remain to be solved. During childhood, parents/caregivers and teachers are mainly responsible for the dispersal of the ideas which concern gender roles, the behavior of their child and student respectively and the social roles that the child / student has to abide to. As a result, they are the first people who affect the socialization process of a child relating to its gender, and they are also responsible for the influence they exert on a boy or a girl to choose socially acceptable careers or occupations for their gender [22]. According to a study by Ji et al. [23], manual occupations are supposed to be male dominated and are thus selected mainly by men. On the other hand, occupations which relate to education, culture and art are traditionally seen as more feminine and for this reason are usually practiced by women.

\subsection{Previous Studies}

There have been numerous studies referring to gender stereotypes in school textbooks, in the past decade, worldwide and that includes Greece. Studies, at a global scale, began in the early 1970s [24,25], while in Greece the first studies appeared in the late 1970s and concerned several thematic issues [26,27,28]. A very interesting study was conducted by Gouvias and Alexopoulos [29], which showed the existence of stereotypical gender representations in the $3^{\text {rd }}$ grade of Greek language coursebooks in primary school. According to the findings of this research, there are strong gender issues concerning stereotypes in the $3^{\text {rd }}$ grade of the Greek primary school both at a coursebook level and in the way in which teachers handle gender issues in the school classroom. Moreover, it is pointed out that images and text references depicting the male gender outnumber the female ones in the coursebook under examination. The stereotypes concerning the roles of the two sexes in society, the way the two sexes are presented in the work field and in family life, are also evident in these textbooks [29].

Taking the above into consideration, it is clear that gender stereotypes concerning occupation and social roles are widespread in the school coursebooks of several subjects which are being taught in primary school. This is one of the reasons why this research was conducted, in the sense that it is important to see whether the English 
language coursebooks which are used in all Greek primary schools are in need of change.

\section{Research Method}

For the needs of the present study, the researchers followed the qualitative method of research. In particular, content analysis was applied, along with semi-structured interviews which were conducted to a number of English language teachers who work in Greek public primary schools (throughout the country).

\subsection{Content Analysis}

For the needs of this study, both qualitative and quantitative research methods were applied. Content analysis was chosen to collect data from the four English language coursebooks (namely from the $3^{\text {rd }}$, the $4^{\text {th }}$, the $5^{\text {th }}$ and the $6^{\text {th }}$ grade) which are used in all Greek primary schools.

The possible existence of gender stereotypes, concerning occupations, will be examined both at a text level and at the level of illustrations which exist within the coursebooks. The results of the analysis will be divided and presented in two categories: a) the text references of occupations, and b) the illustrations depicting occupations.

\subsection{Semi-Structured Interviews}

The research tool for the semi-structured interviews was an interview guide with questions. The interview guide was formed so as to elicit information, from the interviewees, concerning the coursebooks. Thus, the questions were structured following very specific axes.

The first axis includes the demographics of the English teachers who participated in the interviews, such as their gender, their teaching experience and their studies.

The second axis refers to the gender stereotypes which exist in the coursebooks, both at a text level and at a level of illustrations, and which concern occupations. At this stage the results are presented separately for each coursebook.

The third axis deals with the reaction of the English language teachers to the gender stereotypes which exist in the coursebooks. Furthermore, in this axis information was collected on the methods, approaches and techniques which the English language teachers use in their everyday lessons.

The aim of the fourth axis is the possible influence which gender stereotypes may exert on the learner when he or she is on the verge of deciding upon which occupation or job he or she would like to do in the future. In the last part of the interview, English language teachers were asked about their opinion on whether the gender stereotypes which are reproduced in the English language coursebooks affect students later career choice.

\section{Results of the Content Analysis}

\subsection{The $3^{\text {rd }}$ Grade Coursebooks}

The content analysis in the English language coursebook of the 3rd grade 'Magic Book 1' shows that occupation representations at a textual and illustrations level are very limited. More specifically, most of the references pertain to the profession of a teacher, which is represented by a female butterfly, as nowadays mostly women undertake a career which relates to the care and education of children/students [30]. Moreover, several text references and illustrations of Aesop have been observed in MB1 along with many of his myths, as a representative of the writer's or storyteller's profession.

On the other hand, and in a similar fashion to the first volume - MB1 - of the coursebook which is used in the $3^{\text {rd }}$ grade, the second volume of the English coursebook for the $3^{\text {rd }}$ grade - MB2 - does not include many references to professions. However, when we compare it to MB1, it is clear that the references are far more. The textual references and most of the illustrations represent men in professions. This fact can easily be explained as most of the texts derive from Greek ancient myths and classical stories and fairy tales, according to the curriculum, which aid students to learn more efficiently through brief and interesting stories [31].

\subsection{The $4^{\text {th }}$ Grade Coursebook}

The gender stereotypes which relate to professions are easily and very frequently detected in the $4^{\text {th }}$ grade coursebook. The students encounter an abundance of gender stereotypes which refer to occupations. The analysis reveals that the references to males in a professional role outnumber those of females, which is very common in primary school coursebooks [29].

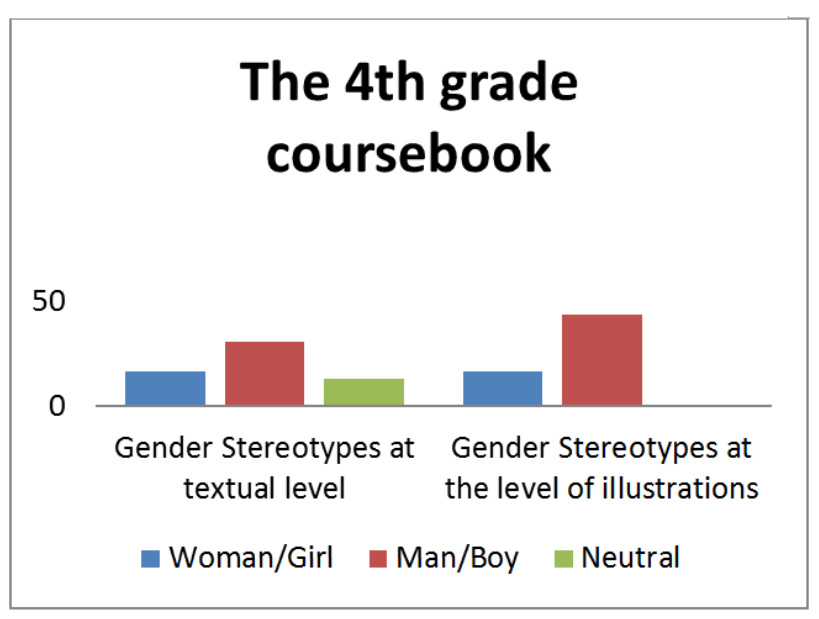

Graph 1. The Content Analysis Results of the $4^{\text {th }}$ grade Coursebook

The majority of the occupations (38\%) which occur in the texts, exercises and instructions are determined by the male gender. A typical example is the profession of the 
Physical Education teacher depicted by a man ([32], p.22) ".... they are talking to their Physical Education teacher, Mr. Papadakis".

Chapter 7 entitled "What are you doing?" also refers to males in professional roles such as that of the doctor "[m]y dad's a doctor and works in a hospital" ([32],p.86), or that of a bus driver, "[m]y dad's a bus driver" ([32], 2009 , p. 86), or a policeman, "[t] his is his police car and he's standing near it" ([32],p.87), or a firefighter "Neil White...firefighter...In this picture he is wearing.." , ([32] p.89), or a baker, "[m]y dad is baking bread in this picture"([32],p.87), or a waiter, "[m]y dad works in a restaurant. In this picture he is serving people" ([32], 2009, p.87), or that of a photographer, “.... an old job, the roving photographer,......... What does he do? ......... he takes..." ([32], p. 92).

The references to women, who play a professional role, are comparatively fewer than those which refer to men, $26 \%$ of the total references to professions in the coursebook are attributed to women. It is important to look closely at the professions which have been selected for the female gender in the texts. Women, most of the times, are encountered as teachers, "[m]y teacher's name is Mrs Stathaki." ([32], p. 10), "Mrs Stathaki wants the children to write a poem." ([32], p. 70), "Mrs Stathaki: Good morning children" ([32], p. 98), "[t]he children are talking to Mrs Stathaki...” ([32], p. 106), ([32], p.131) "[h]er teacher Alice White" ([32], p. 131).

This image is also confirmed by the illustrations which exist in the specific coursebook and are used as educational tools for teaching a foreign language. Coursebook illustrations transmit values and beliefs and are also very popular amongst the students [33]. It is very surprising to see that most of the illustrations represent males in professional roles, the number of which is twice as many as those illustrations representing females.

It is very important to note that students who are reading this coursebook encounter a distorted reality since the stereotypes which appear in the book show the male gender occupying professions and jobs such as that of the Physical Education teacher, the professional athlete, the doctor, the firefighter and the bus driver, in other words jobs which need physical strength and stamina as well as mental strength. Furthermore, the male gender is depicted as the only one which is able to deal with matters of authority such as the job of a policeman or a traffic warden. On the other hand, the preconceived ideas which are reproduced throughout this coursebook place women in professions such as that of a teacher, a nurse, a hairdresser or a shop assistant, in other words in occupations which relate to health, education and care. As a result, it is evident that the student will subconsciously shape his or her beliefs and attitudes concerning gender and the choice of a profession according to the stereotypical ideas depicted in the coursebooks [12].

Taking the above into consideration, it must be stressed that the neutral gender references in this coursebook are minor and not detected in the basic texts of the coursebook's units, although the school coursebook which is the main teaching material which is used in Greek primary schools should present all jobs and occupations as gender-neutral [34].

The last matter which should be taken into consideration, as concerning this coursebook, is that housework has been allocated equally to both genders, while it is interesting to see that most of the times housework is distributed to a boy and only once to a girl, something which is quite surprising given the fact that there exists inequality between the two sexes in the coursebook.

\subsection{The $5^{\text {th }}$ Grade Coursebook}

The analysis of the coursebook's contents (texts and illustrations) of the $5^{\text {th }}$ grade of primary school showed that the majority of the references which concern occupations relate to the male gender. In this coursebook there are very few references made to occupations in connection to the female gender. There is also no chapter which makes reference to occupations and jobs in the specific book. Neutral references to professions and jobs are many more compared to the references made to female job holders but, again, these references do not play a central role in the coursebook. Textual references which concern occupations directed to men in the coursebook constitute the majority (61\%) compared to the references which concern occupations for women (16.7\%). Neutral references $(22.2 \%)$ to professions, at a text level are also worth noting.

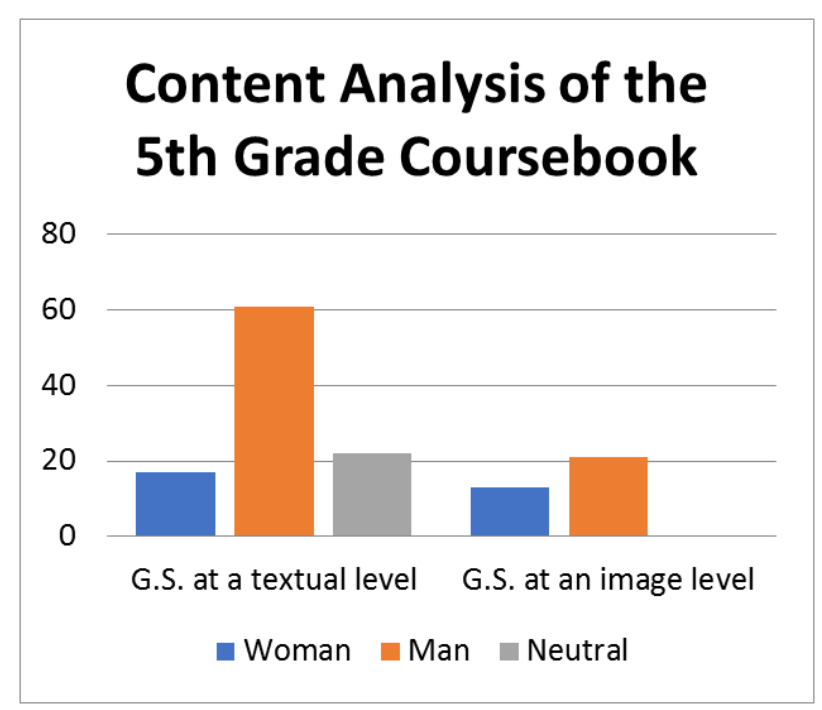

Graph 2. The Content Analysis Results of the $5^{\text {th }}$ grade Coursebook

In the primary school Student's Coursebook we find several references to historical male figures / leaders, "Karlomagnos.... Konstantinos Palaiologos... Mohamed II" ([35], p. 89), or famous male painters, "El Greco had a 
very individual style.... He is one of the most famous painters of the 16th century. His paintings have influenced many famous artists after him, for example Picasso and Cezanne" ([35],p. 88), "[t]hey are very interested in a painting by Mark Chagall called I and the Village" ([35], p. 127), mention is also made to a famous playwright, "[w]e don't know much about William Shakespeare... Shakespeare wrote Comedies, Histories and Tragedies." ([35], p. 86), and "[w]hat was the name of Shakespeare's theater?" ([35], p. 95). The majority of the athletes are represented by men, “... like any other professional sports person" ([35], p. 30), "[i]n 2005 Pele', the famous footballer, ..." ([35], p. 31), "Yiannis Kouros: the Greek ultra-distance runner..." ([35], p.113). In addition, there are references to the profession of a male police officer, " $[\mathrm{t}] \mathrm{he}$ policeman is interrogating Jack Smith about the robbery... the conversation between the policeman and Jack Smith..."([35], p. 90), "[w]hat do you think Mrs. White said to the policeman?" ([35], p. 93).

In the same coursebook we come across manual occupations which are carried out by males such as the job of a fisherman, "[o]ne morning, the fisherman went fishing..."([35], p.108), or the job of a farmer, “....dad is always busy with the farm. " ([35], p. 76) as well as the job of a craft worker "My parents work in a factory..." ([35], p. 38).

Finally, with respect to the other professions that appear to be represented by men, we observe occupations that require a combination of skills such as intelligence, management skills and responsibility, such as those of the entrepreneur, "......he set up his own company" ([35], p.124), or that of a ship owner, "Onassis..a famous ship owner " ([35], p.89), or even that of a bookstore owner, "[m]y father is a shop owner... his bookstore" ([35], p. 38 ), or that of the owner of a public relations company, " [h]e runs a public relations company .." ([35], p. 78), or that of the inventor, "...he invented the helicopter ..." ([35], p. 124), and last but not least that of the astronaut "[h]e has stepped on the moon' ([35], p.119)'. Women, on the other hand are referred to as headmistresses, "Mrs Clark, the school headmistress..." ([35], p.26), "Mrs Clark invites all parents..." ([35], p.27), of the bank employee, "[m]y mum who is a bank clerk ..." ([35], p. 38), or the circus performer, "[s]he works as a performer in a circus..." ([35], p. 78), or even a painter "..famous Irish artist Bernadette Madden" and that of an actress, "[f]amous actress gives birth to a baby girl" ([35], p.118).

It is not surprising to see that manual occupations, occupations with some authority and those that confer recognition at a financial or social level are attributed to the male gender, both at a textual level and at the level of illustrations [17]. On the other hand, women within the coursebook have been given occupations that are concerned with the upbringing and education of their off-springs, or jobs which relate to their artistic nature or that do not require any particular physical or mental skills, since women are considered good at doing some things but are not particularly capable [18]. Neutral references are called upon to alleviate the disproportionate image created by the gender stereotypes of the professions which exist within the coursebook [36]. But even they are very few and exist mainly in exercises and utterances that invite students to carry out a dialogue amongst themselves or to play a role [37].

However, the professions represented by men (textual and/or illustrations) outnumber those represented by women in the 6th grade Student's Coursebook [38-29]. This is also observed in the other school subjects' coursebooks [39]. But what is particularly important is the nature of the professions assigned to each sex. As illustrated above in the Greek primary school Student's Coursebook, men are once again given more 'energetic roles' which require creativity, extraordinary physical and mental abilities, responsibility, and artistic tendencies, while women are mainly involved in jobs which focus on child care (teacher, nurse), but also on jobs that do not make physical or mental demands on women [17-23].

\subsection{The $6^{\text {th }}$ Grade Coursebook}

In the $6^{\text {th }}$ grade Student's Coursebook many references are made to the profession of a male actor [38], ".. an actor that is known as the best spy agent" ([40], p.109), "[w] ho is your favorite actor to play 007?" ([40], p. 110). Still, more professions seem to be heavily tinged with a male flavor in the $6^{\text {th }}$ grade coursebook as are the pilots "Wilbur and Orville Wright invented the first airplane" ([40], p. 39), or of the professional Paralympian athlete "[h]e has been a champion...20 years " ([40], p. 80), and also the "...famous Paralympics champion Kostantinos Fykas" ([40], p. 81) as well as the famous film director “[d]irector Steven Spielberg” ([40], p.145).

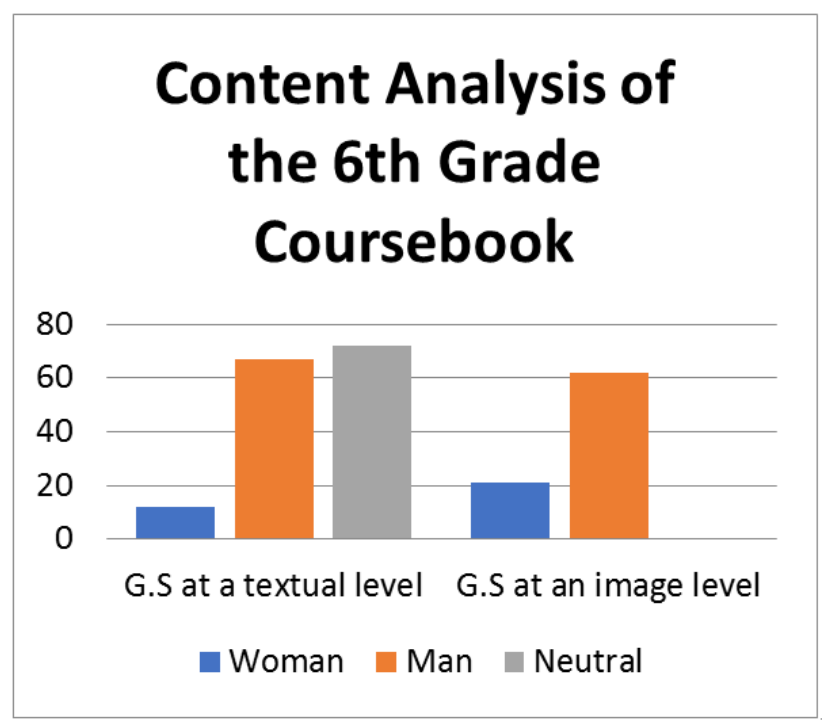

Graph 3 - The Content Analysis Results of the $6^{\text {th }}$ grade Coursebook

There are some references to professions encountered 
by male practitioners, such as the policeman's profession “... as a nice policeman... [h]e looks handsome .." ([40], p. 133), that of the taxi driver "John's father drives a taxi" ([40], p.147), or the composer "Andrew Lloyd Weber, the British composer .." ([40], p.74), the author “... Julius Vern ([40],p.41), followed by "[a] novel written by Charles Dickens" ([40], p.109), and the painter "Peter Brueghel" ([40].46), also the job of a waiter "...or of a waiter.." ([40], p.67) and the King's axiom "King Louis XVI.... King Minos..." ([40], p.47).

As for the cases in which women are presented as professionals, they are confined to the profession of an actress "[a]ctress / star: Dakota Fanning (Rachel Ferrier)" ([40], p.145), or a teacher "Mrs. Green... the teacher .." ([40], p.98), or a stewardess "[t]he airhostess .." ([40], p. 42 ), or an artist-painter "Maria will probably become an artist." ([40], p.69), and in the role of a housewife “...'b' a housewife" ([40], p.67, see also [38], 2014). Women are also portrayed as queens in some texts "..... queen Marie Antoinette .." ([40], p. 47) and unconventionally as a pilot "She can fly a plane"([40], p.150).

\section{Results of the Semi-Structured Interviews}

\subsection{First Axis - Teachers' Demographics}

The survey involved nine English language teachers from different cities in Greece, of whom only one was a male. The teachers' teaching experience varied from two to twenty-two years and all of them mentioned that they had taught English in all the grades of primary school. Most of them have a BA in English Language and Literature, while three have completed postgraduate studies in Foreign Language Learning and Teaching at the Aristotle University of Thessaloniki, Department of English Philology.

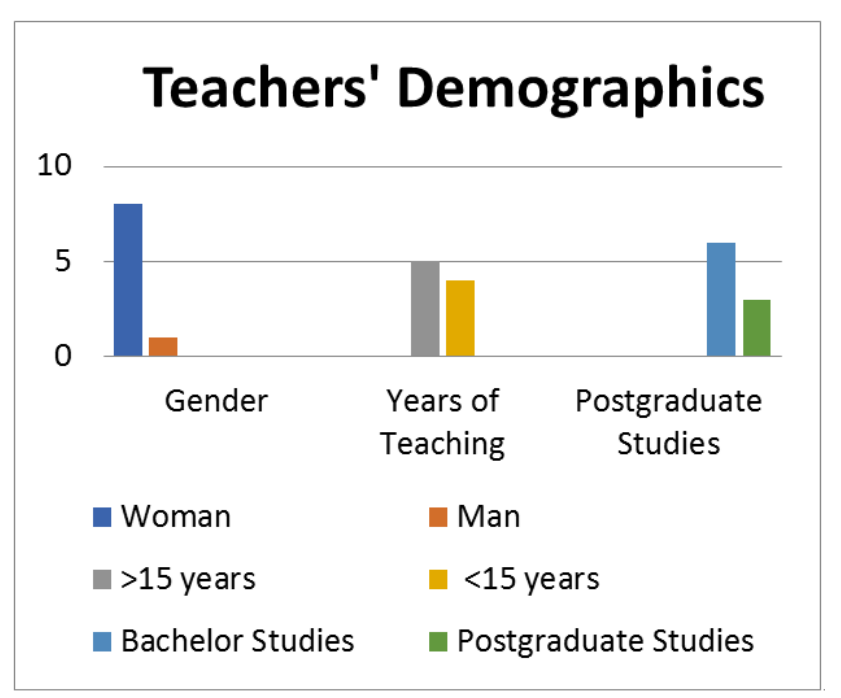

Graph 4. The Teacher's demographics: gender, years of teaching, and studies

\subsection{Second Axis - Teachers' Answers Concerning Gender Stereotypes Which Are Found in the English Language Coursebook's Texts and Illustrations}

Concerning the gender stereotypes which appear in the texts of the course book in the third grade, teachers consider them to be scarce - even non-existent - and when they do exist, they are observed within the context of stories that come from old myths and thus carry the perception of the specific era. Teachers seem to have a similar opinion about the existence of stereotypes at an illustrations level. Although two out of the nine teachers, who participated in the research, mentioned that they believe there are some stereotypes at an illustration level, especially when they compared the coursebook's illustrations to the texts (T2, T6), the majority of the teachers also believe that grade 3 students do not understand gender stereotypes. Only one English language teacher claimed that students perceived gender stereotypes through illustrations, were influenced by what they saw, and chose their profession because of their gender. According to the aforementioned teacher, students of this age group reproduce stereotypical perceptions which they hear without understanding their meaning.

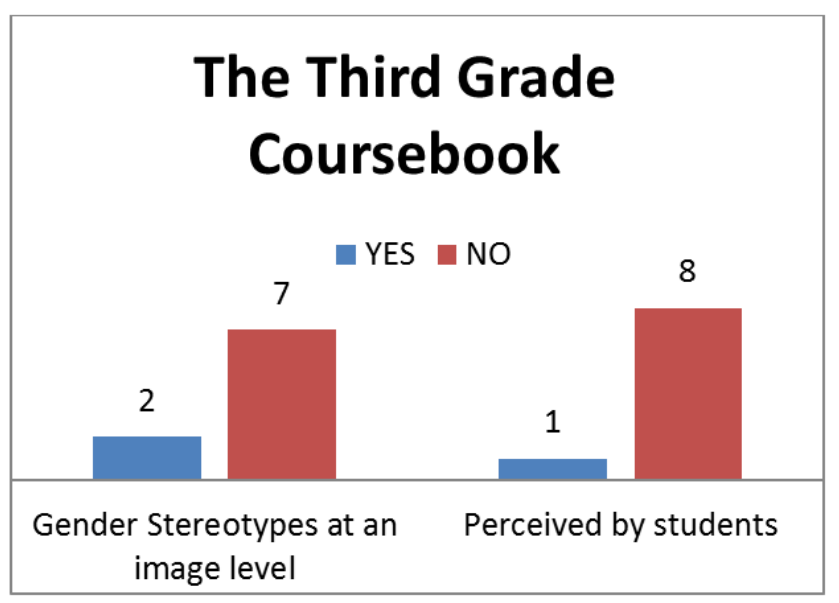

Graph 5. Results - Teachers' Answers concerning the $3^{\text {rd }}$ Grade Coursebook in Greek Primary Schools

Most teachers concluded that the limited number of stereotypes that exist in the coursebooks of the $3^{\text {rd }}$ grade create a neutral image for the students, except teacher 2 (T2), who stated that "[s]tudents attending smaller grades identify with the different professions we find in the coursebook and create fantastic scenarios which are generally a 'fun time' for them." 


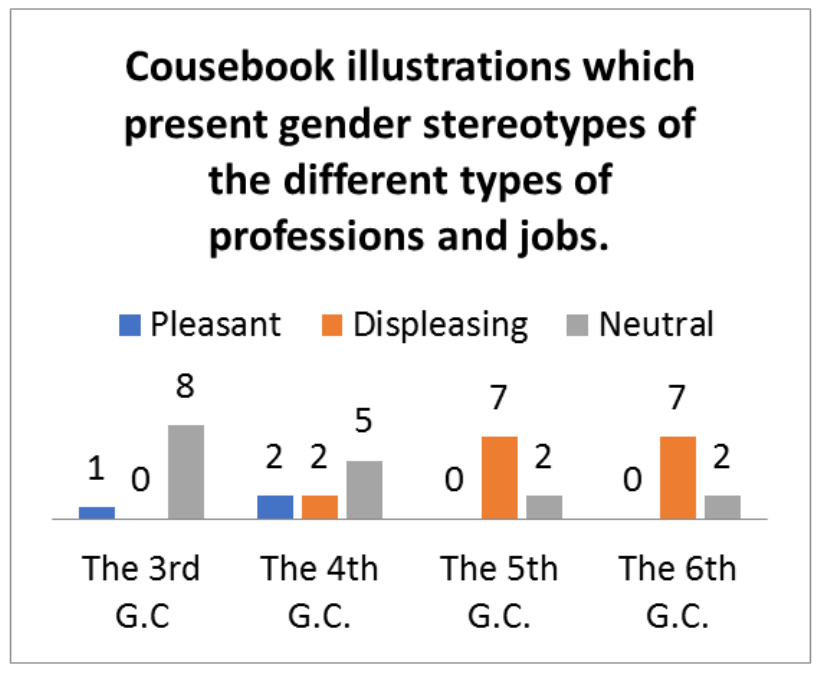

Graph 6. Results - Teachers' responses to the illustrations which exist in the English language coursebooks and which depict gender stereotypes. (*G.C. $=$ Grade Coursebooks)

The responses of the teachers' concerning the 4th grade coursebook are different. According to the majority of the respondents ( 8 out of the 9 teachers), the English coursebook for the 4th grade contains gender stereotypes in both its textual level and illustrations level. This is very vivid in Unit 7 which is entitled "[w] hat are you doing?". Teacher 9 (T9) mentions that "[t]here are some stereotypical perceptions, but to a point they reflect reality". These stereotypes, according to the majority of the teachers ( 7 out of the 9 teachers) who were interviewed, are perceived by most pupils. Pupils were able, mainly, through the coursebook's illustrations, to pick out a large variety of professions which were attributed to men compared to women. Very often students express their curiosity verbally (T4), some boys make derogatory comments about what they read or see in the coursebook (T1) or sometimes male students agree with what is said in the book (T5).

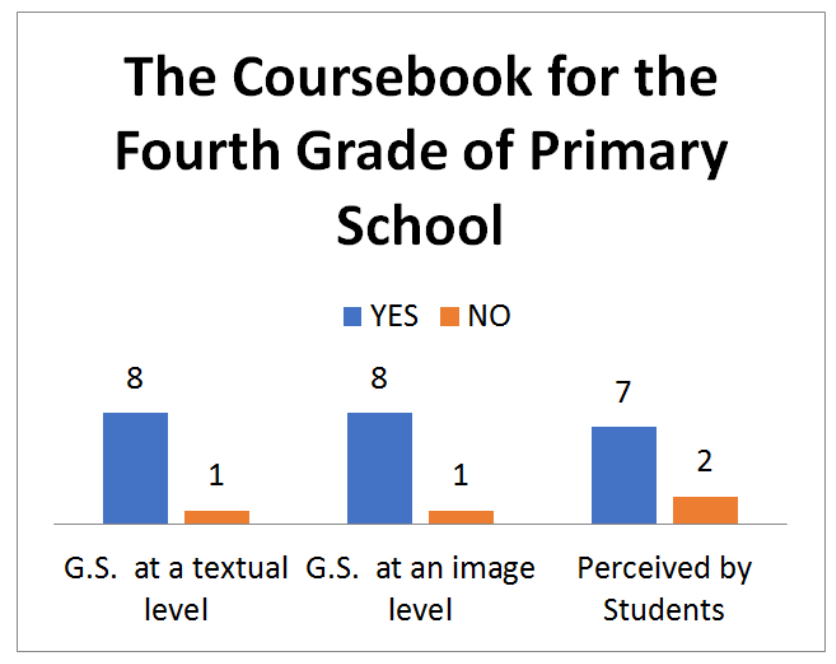

Graph 7. Results - Teachers' Answers concerning the $4^{\text {th }}$ Grade Coursebook in Greek Primary School
In addition, more than half of the $4^{\text {th }}$ grade primary school teachers believe that gender stereotypes which concern professions in the $4^{\text {th }}$ grade coursebook create neither a pleasant nor a displeasing picture for their students. Students of this language and age level do not disagree or dispute at what the coursebook says. However, two teachers $(\mathrm{T} 1, \mathrm{~T} 8)$ believe that the stereotypes which exist in the coursebook create an unpleasant feeling to most $4^{\text {th }}$ grade students who seem to be dissatisfied with the coursebook's illustrations and its texts. Finally, it is interesting to read the opinion of the other two teachers (T2, T5) who believe that gender stereotypes create a pleasant image for pupils. More specifically as T2 says: "I think that until elementary school students are happy to read and see the different types of occupations in their stereotypical forms within their coursebooks. This is perhaps due to the fact that they are familiar with these stereotypes through the toys they were given to play with and through the environment in which they grew up, not to mention that they feel safer when they see or read about the same stereotypes within a foreign language coursebook".

\section{The 'picture' which gender stereotypes form concerning jobs and occupations}

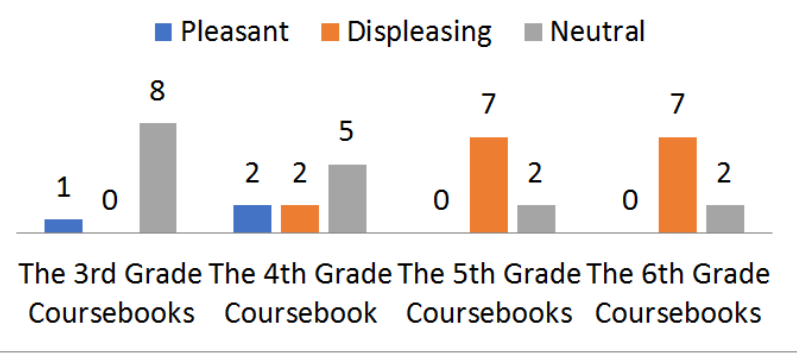

Graph 8. Results - Teachers' responses to the 'picture' created by gender stereotypes within the coursebooks

The $5^{\text {th }}$ grade English language coursebook, according to the teachers (that is eight out of the nine teachers who participated), contains gender-related stereotypes that are found in both the texts and the illustrations of the coursebook. According to T4, "[y]es, texts that depict occupations are usually accompanied by images which bear gender stereotypes". T3 asserts that "[t]hey [meaning gender stereotypes] exist in occupations, as men or boys are often depicted in more dynamic, active and vibrant professions than girls or women". Thus, we see manual occupations attributed to men in English language coursebooks for primary school students in Greece, and care giving and education to women [23].

Similarly, almost all teachers agree that students 
identify gender stereotypes in their coursebooks through the illustrations of the coursebook which they are using and the dialogues and role play which they are asked to perform, the same applies in the case of the analysis of texts which exist within the coursebook and which they [the students] are asked to read. Sometimes, though, students tend to compare the stereotypes of their coursebooks with their surrounding environment, especially their families and friends, which are often carriers of such perceptions, and this is where these students find many differences [10]. It is worth mentioning T4's view on how students perceive stereotypes, "[i]n grade five, all children begin to express their preferences on different kinds of professions. It is striking to see that if an illustration presents, for example, a female hairdresser and a boy expresses his desire to become a hairdresser [not a barber], then his classmates respond by saying that «[i]n the book she is a woman, you can't become a hairdresser so choose something else!" That is, they treat the book as an authority, "[a]fter all, it has been observed that students adopt perceptions of gender more strongly in language coursebooks" [21].

According to other views, students dispute and quarrel over gender stereotypes. The boys, mostly, applaud the book's illustrations and ridiculed the girls who question the textbook and often disapprove of the gender stereotypes which exist within them.

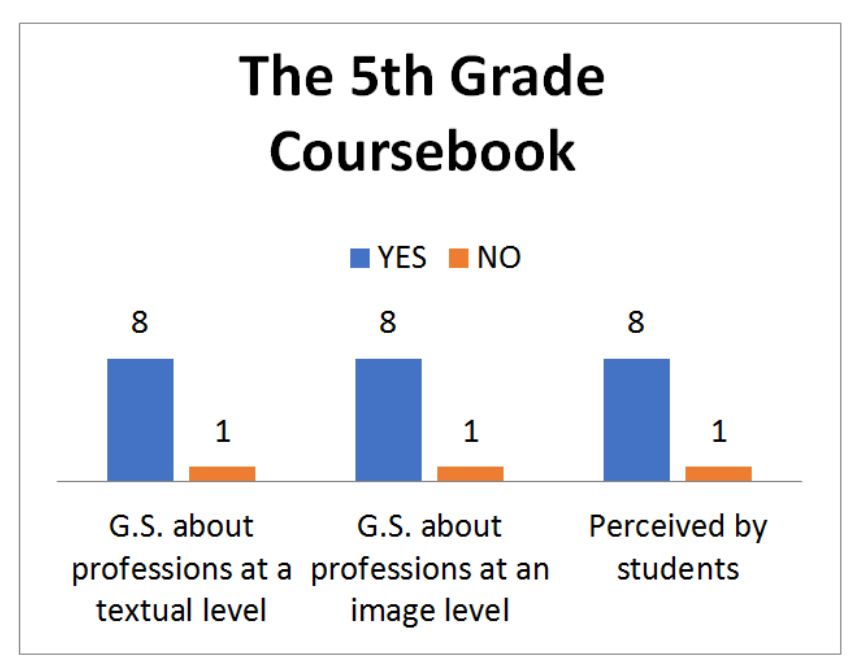

Graph 9. Results - Teachers' Answers concerning the $5^{\text {th }}$ Grade Coursebook in Greek Primary School. $\left({ }^{*}\right.$ G.C. $=$ Grade Coursebooks)

For most of the teachers interviewed (seven out of the nine teachers who participated) it is evident from the students' reactions that gender stereotypes create an unpleasant picture for the $5^{\text {th }}$ grade elementary coursebook. Most of the teachers' viewpoints converge on the fact that female students are largely aware of the gender differences between male and female professions, which leads to a controversy and negative comments, even to quarrels between and amongst students. T2 states that "[i]n the last grades I find that some illustrations cause unpleasant feelings to them, especially to girls. They are now beginning to understand that women are destined by society to do specific professions" [11,41]. Finally, it should be noted that two of the teachers believe that gender stereotypes cannot influence a student's perception of the coursebook, either positively or negatively.

\section{The 'pictures' created by gender stereotypes which concern professions and jobs}

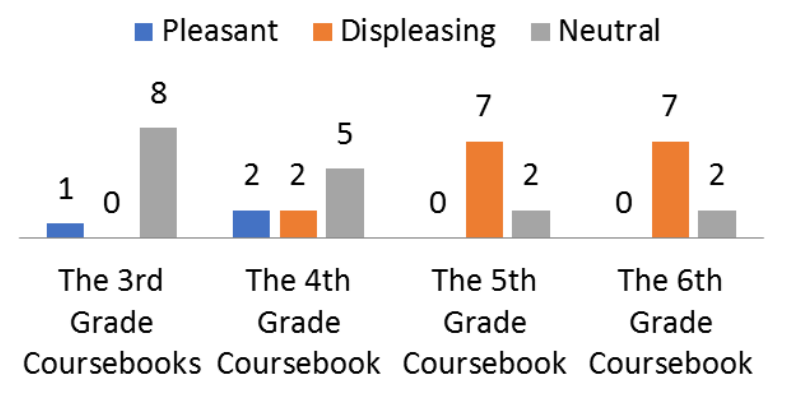

Graph 10. Results - Teachers' responses to the 'picture' created by gender stereotypes within the coursebooks

As concerning the $6^{\text {th }}$ grade coursebook, all teachers, except T9, agree that there are gender stereotypes concerning professions and jobs in the $6^{\text {th }}$ grade. Gender stereotypes exist both at a text level and an illustrations level. Stereotypes are significantly more intense in the $6^{\text {th }}$ grade English language coursebook, compared to all the previous coursebooks which are mentioned above, especially in chapter 6 entitled, "Me, myself, and my future job". The stereotypes which the teachers perceive are also perceived by their students.

\section{The 6th Grade Coursebook}

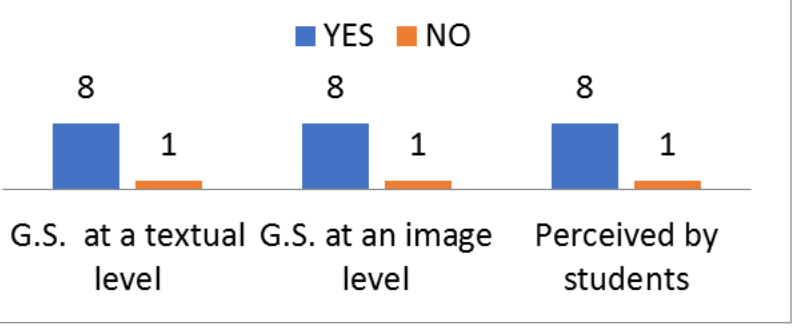

Graph 11. Results - Teachers' Answers concerning the $6^{\text {th }}$ Grade Coursebook in Greek Primary School. $\left({ }^{*}\right.$ G.C. $=$ Grade Coursebooks) 
In this class, the understanding of English texts is straightforward. In the classroom, the girls' disapproval of some quotes, excerpts and illustrations from the coursebook is very intense. This leads to controversy and derogatory comments on the part of the boys. According to $\mathrm{T} 1$ "[c]onflicts are also observed in the $6^{\text {th }}$ class of primary school because of the stereotypes which exist. A typical comment made by a boy to a girl who expressed her desire to become a doctor was "[y]ou will become a nurse and you will marry a doctor" while T5 said "[h]ere the disapproval comes from girls but boys, also understand that there is a tendency to categorize occupations depending on the gender".

What applies to grade 5 also applies to grade 6 , in other words, seven out of the nine teachers find the illustrations of the coursebook unpleasant.

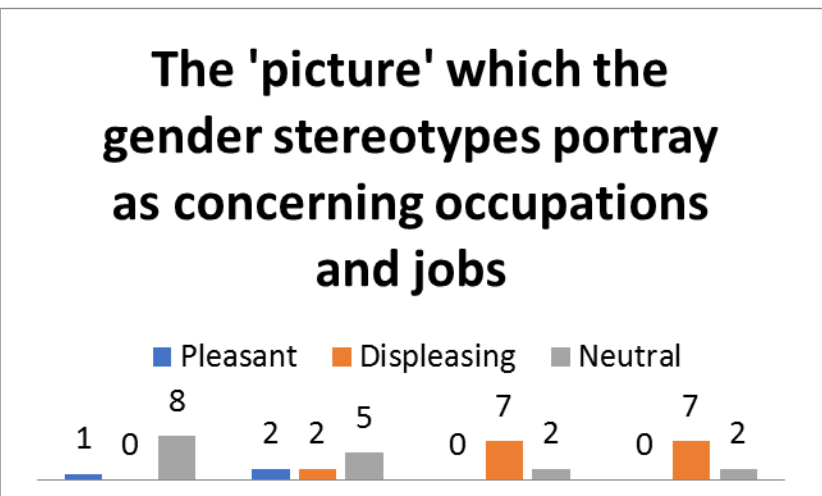

The 3rd G.C. The 4th G.C. The 5th G.C. The 6th G.C.

Graph 12. Results - Teachers' Answers Concerning the Pictures Created in the Coursebooks $\left({ }^{*}\right.$ G.C. $=$ Grade Coursebooks)

This is largely due to the confusion and the negative comments made mainly by female students who express their desire for a "male" profession which the coursebook promotes, and are deterred by their peers' derogatory comments. According to T7, "I believe that because female students receive different stimuli in the modern society within which they live, they cannot identify with the stereotypes which exist in the coursebook and thus believe it [the coursebook] to be obsolete".

\subsection{Third Axis - The Teacher's Teaching Methodology and the Activities Which They Apply and Which Influence The Students' Choice of Professions and Jobs}

The majority of the English language teachers who were asked about the teaching methods which they applied, mentioned that their goal was to focus on their students' needs, thus they applied group-work. However, about half of the teachers (T1, T2, T4 and T9) stated that, due to time pressure, the translation of the necessary vocabulary is the only solution especially when explaining grammatical phenomena. The teaching approaches which are followed by the majority of the teachers, who were interviewed, are those that help students to apply their skills. Teachers may also apply activities that support learning in an active manner. They may also use texts or the content of some texts to support their student' learning. Some teachers mention that they base their teaching on learning through the discovery of knowledge but, where necessary, the new vocabulary is translated - in the mother tongue - to their students (by the teachers themselves). According to the teachers, the most commonly used activities suggested by the curriculum are vocabulary games, short stories combined with audiovisual material, pantomime, songs, and dance [5-42-43]. For the larger classes, they usually devote time to groupwork and projects, drama activities and dialogues in pairs or even in groups [37-44]. Two of the teachers mentioned that in their daily practice they apply peer-assessment and self-assessment through worksheets and reinforcement exercises.

When asked if there are activities in the coursebook of grade 3 which are affected by gender stereotypes, most teachers agreed that the coursebook does not contain such activities. However, almost everyone (except T9) believes that English coursebooks for 4th, 5th and 6th grade students contain activities which concern the student's choice of a profession and which are influenced by gender stereotypes.

\section{The existence of activities that are influenced by gender stereotypes}

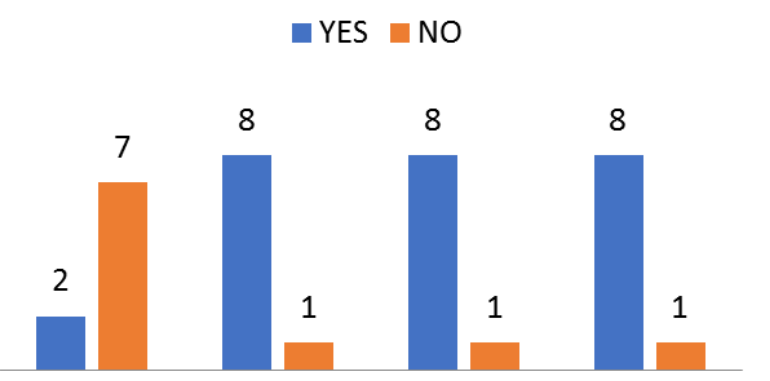

The 3rd G.C. The 4th G.C. The 5th G.C. The 6th G.C.

Graph 13. Results - Teachers' responses concerning the existence of activities in relation to the choice of professions or jobs that are influenced by gender stereotypes

Teachers noted that activities which allocated professional roles to students were highly influenced by gender stereotypes and the same applied to dialogues and 'act-it-out' roles. Furthermore, they mentioned that oral and written activities in which students expressed their 
preference for specific occupations or their parents' occupations were also highly influenced by gender stereotypes. More specifically it was reported by T1 that "[i]n the English language coursebook of the $5^{\text {th }}$ grade of primary school, there is a portfolio activity in which students are invited to interview a famous athlete or artist. I've noticed that because there is a sample interview which is directed to a male athlete, most of the students also tend to choose to interview a famous male athlete. Girls are often not influenced by the sample interview but they still tend to ask me if they can choose a woman; for them it is not self-explanatory that they can choose whoever they like. Students, males and females, are heavily influenced by their coursebook". According to T2 "[t]here is an activity in the $6^{\text {th }}$ grade coursebook in which students are expected to talk to each other about their skills and at the end of their collaboration and discussion they are expected to choose a profession based on these characteristics. It is common for students to abide to the stereotypes of the coursebook irrespective of their individual preferences and choices".

\section{The influence of gender stereotypes in the students choise of a future career}

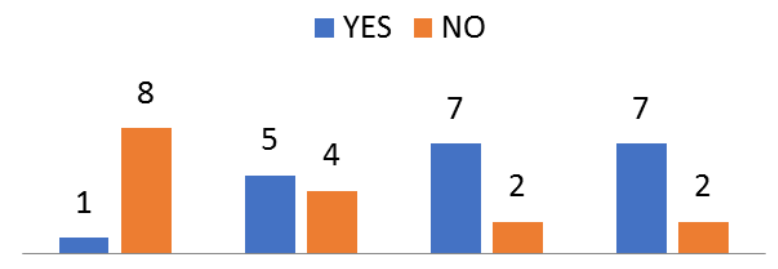

The 3rd G.C. The 4th G.C. The 5th G.C. The 6th G.C.

Graph 14. Results - Teachers' answers on the influence the school exerts on the career choice of the students

Finally, teachers report that when a student in the $4^{\text {th }}$, $5^{\text {th }}$ and $6^{\text {th }}$ grade asks them about the gender stereotypes (concerning the different kinds of professions and jobs) which exist in their coursebook, their answers (meaning the teachers' answers) are generally soothing in the sense that they (the teachers) tell them that these choices are random. Their goal, as most teachers stress, is not to allot professions or jobs to a specific gender group, but to encourage students to follow their innate tendencies, preferences and abilities, as T3 says, when asked a question by a $4^{\text {th }}$ grade student concerning occupations and gender stereotypes, "I tried to explain to my students that things have changed over the course of time and that there are no male and female occupations today". A similar response was given to a $5^{\text {th }}$ grade student,"... a profession should be practiced by someone who likes it, in other words he or she likes what he or she does, skills do not always play an important role as you can always improve yourself through practice". On the other hand, T9 replied that " $[i] n$ the $6^{\text {th }}$ grade a stereotypical question which is asked by boys is whether the profession of a doctor or a firefighter is fit for a woman. I usually answer by saying that maybe these professions and jobs are more dangerous for women and that maybe they require more strength, and that perhaps this is the reason why men usually do better in them but there are women police officers who are placed in less dangerous posts and are thus able to do the job as well as any man".

\subsection{4th Axis - Teachers' Responses to the Possible Influence of Gender Stereotypes in the Choice of Their Future Profession or Job}

At the end of the interview, teachers were asked to respond to the question of whether gender stereotypes influence an individual's later career choice.

According to the majority of the teachers, the choice of a future profession is not influenced by the coursebook of the $3^{\text {rd }}$ grade of primary school as they (the teachers) do not think it contains gender stereotypes concerning professions and jobs. As for the 4th grade of primary school, five out of the nine respondents believe that gender stereotypes which exist in the coursebook may have a long-term impact on a person's career choice. More specifically, T2 states that "[t]hey [meaning the students] are undoubtedly influenced by women's and men's professions. They [meaning the students] are subconsciously impressed and influenced and as they grow up, they get the idea that they will 'have to' follow a certain career path based on their gender. It is most certainly a combination of stimuli and social and environmental influences that trigger a student to make a specific profession or job choice, but the primary school coursebooks certainly contribute to all this". It is worth noting that seven of the nine teachers mentioned that gender stereotypes in the coursebooks of the last two grades of primary school could influence students on their career choice later in life. More specifically, as T4 mentioned, "[t]he coursebook of the 4th grade confirms the perception of how society views professions and jobs in connection with gender. It is certainly not the only thing that defines the choice of occupation. But, imagine, if most of the students' coursebooks contain stereotypical concepts, isn't it natural - then - that they will become influenced in their career choices, to some degree, sooner or later". In a similar vein $\mathrm{T} 1$ mentions that, "[t]hey are deeply influenced by the $6^{\text {th }}$ grade coursebooks and the stereotypes which it 'carries with it', mainly at an illustration level. Social views on the choice of a profession or a job are confirmed through the illustrations which exist within the coursebook and its texts. However, I strongly believe that the student is influenced by both his or her family as well as the wider social environment 
within which he or she is growing up". On the other hand T9 mentioned that, "I do not think that students are influenced by their coursebook when choosing a profession or a job. In my opinion parents and their daily life are what influence their career choice".

We conclude that teachers consider, to a certain extent, that gender stereotypes which exist in the $5^{\text {th }}$ and $6^{\text {th }}$ grade English language coursebooks do influence students' future career choices. Nevertheless, they are convinced that the stereotypes which exist in the coursebooks confirm social perceptions and act in a complementary manner to the influence which is exerted by the student's family and the environment within which he or she lives. The coursebook, on the other hand, because of the important role which it plays in the Greek schooling system, is treated - by all - as an indisputable authority in the school environment, which not even the teacher would dare to question or dispute. As T7 so rightfully puts it, "[i]t is possible that students will be influenced in their choice of professions and jobs later on in their lives because of the stereotypes they come across in their coursebooks, however, in my opinion, this influence can be minimized by their teachers, whenever the teacher deems that this is necessary. After all, students are strongly influenced by their teachers' attitudes and perceptions" $[12,20]$.

\section{Limitations}

This research focused upon the presence of gender stereotypes, in English language coursebooks, in the $3^{\text {rd }}$, $4^{\text {th }}, 5^{\text {th }}$ and $6^{\text {th }}$ grades of primary school and the possible effect that stereotypes have on students' future occupation, career and job choices. It is, nevertheless, very important to consider the limitations of the present research.

Firstly, one of the limitations of this study is the number of English language teachers who participated in the interview. A larger sample of teachers could give a clearer picture of their attitude towards gender stereotypes (which exist in English language coursebooks). This study is also limited to English language coursebooks in Greek primary schools. A study on more school subjects, which are taught in primary and/or secondary schools in Greece, would probably lead to a more secure stance on the way the educational system in Greece has chosen to present gender stereotypes, especially those which are connected to occupations/professions/jobs in coursebooks.

\section{Conclusions}

The main objective of this research study was to focus on the process of detecting the gender stereotypes which exist in English language coursebooks in Greek primary schools, which refer to occupations and may thus influence students' future career choices.
The research questions centered around the existence of gender stereotypes concerning professions and jobs in English language coursebooks of the $3^{\text {rd }}, 4^{\text {th }}, 5^{\text {th }}$ and $6^{\text {th }}$ grades of Greek primary schools and more specifically the frequency with which they appear at a textual and an illustration level in the coursebooks of the aforementioned grades. The last research question concerned the possible impact these stereotypes may have on the student's choice of a future profession or job.

In view of the research questions presented above, it was assumed that no gender stereotypes, in relation to professions, exist in the English language coursebook Magic Book 1 and 2 of the 3rd grade. Albeit, the myths in Magic Book 2 are performed solely by males, it is quite clear that due to the fact that these myths refer to times gone by and that they were written many centuries ago, they present facets of life which do not exist anymore and of which the students are aware. At this point, it should be noted that the contents of the coursebooks could have been presented differently thus giving a chance to the female gender to be represented in non-stereotypical roles too.

The majority of the teachers ascertained the findings of the content analysis referring to the fact that the stories focus on language teaching through intuitive and brief stories rather than on professions [43]. Furthermore, most of the teachers claim that the students do not notice the gender stereotypes in the coursebook of the $3^{\text {rd }}$ grade and therefore the book does not affect their future career choice.

On the contrary, according to the findings of this research, the English language coursebooks of the $4^{\text {th }}, 5^{\text {th }}$ and $6^{\text {th }}$ grades present vivid stereotypes which are associated with both genders and which refer to professions and jobs. In these three coursebooks, the references to working men obviously outnumber the ones which refer to working women. The illustrations are more representative of these findings, as they are instantly observed by students and have a stronger impact on the way they form their attitudes [33].

The texts along with the illustrations of the $4^{\text {th }}, 5^{\text {th }}$ and $6^{\text {th }}$ grade coursebooks shows a clear picture that men undertake most of the manual jobs as well as the ones which demand control, management and mental skills. On the other hand, professions associated with education, health care, the care of children and the arts, which do not demand physical or mental skills, are performed by women. This image confirms the social stereotypes that attribute different roles to men and women [17,23].

Nonetheless, the use of neutral references to several occupations at a textual level is obvious in an effort to render the school coursebooks gender- neutral [34]. However, these neutral references do not appear in the main passages and thus they do not really alternate the stereotypical image of the coursebooks.

Most of the teachers affirm the existence of gender 
stereotypes (in the coursebooks) associated with professions and jobs [21]. Teachers claim that these stereotypes are easily observed mainly by female students in the last grades of primary school.

As far as the last research question is concerned, it is assumed that the gender stereotypes which concern occupations and jobs and appear in the $4^{\text {th }} 5^{\text {th }}$ and $6^{\text {th }}$ grade coursebooks may influence and perhaps even shape students' attitudes towards a future career choice. According to most of the teachers, this influence can be reinforced or it can also be diminished by the teacher if appropriately approached, as the teacher can influence his or her students through the transmission of ideas and attitudes [12-20]. Overall, teachers believe that career choices are the result of a combination of factors, the most significant of which is the influence the family exerts on the student as well the social perceptions which exist within the society in which the student lives [10].

\section{REFERENCES}

[1] D. Gouvias, C. Alexopoulos. Sexist stereotypes in the language textbooks of the Greek primary school: a multidimensional approach. Gender and Education, 30 (5), 642-662, 2016. DOI: 10.1080/09540253.2016.1237620.

[2] M. Bertrand. New perspectives on gender. In Handbook of Labor Economics (vol. 4, pp. 1543-1590), Elsevier, 2011.

[3] G. E. Britton, M. C. Lumpkin. For sale: Subliminal bias in textbooks. Reading teacher, 31, 40-45, 1977.

[4] A. Sule, E. Seda, M. Ipek. Gender Stereotypes in the Classsroom and Effects on Achievement. The Review of Economics and Statistics, 100 (5), 876-890, 2018. ISSN 0034-6535.

[5] A. Sougari. Teaching English in the Primary Classroom. A Guide for teaching practice. Thessaloniki, University Studio Press, 2000.

[6] L. Cameron. Teaching Language to Young Learners. Ernst Klett Sprachen, 2001.

[7] B. Tomlinson, H. Masuhara. Developing Cultural Awareness Integrating culture into a language course. Modern English Teacher, 13 (1), 5-12, 2004.

[8] C. Puren. La compétence culturelle et ses différentes composantes dans la mise en oeuvre de la perspective actionnelle: une problèmatique didactique. Intercâmbio: Revue d' Études Françaises= French Studies Journal, 7, 21-38, 2018.

[9] D. L. Ball, D. K. Cohen. Reform by the book: What is-or might be-the role of curriculum materials in teacher learning and instructional reform? Educational Research, 25 (9), 6-14, 1996.

[10] Eccles J. Gendered educational and occupational choices: Applying the Eccles et al. model of achievement-related choices. International Journal of Behavioral Development,

$$
35 \text { (3), 195-201, } 2011 .
$$

[11] D. M. Baunach. Trends in occupational sex segregation and inequality, 1950 to 1990. Soc.Sci.Res, 31, 77-98, 2002. DOI: $10.1006 /$ ssre.2001-0719.

[12] S. S. Spencer, M. Q. Claude, M. Diane. Stereotype threat and women's math performance. Journal of Experiments Social Psychology, 35 (1), 4-28, 1999.

[13] L. L. Lindsey. Gender Roles: A sociological Perspective (6th ed.), New York, Routledge, 2015.

[14] L. Evans, K. Davies. No sissy boys here: A content analysis of the representation of masculinity in elementary school reading textbooks. Sex roles, 42 (3-4), 255-270, 2000.

[15] M. Kollmayer, B. Schober, C. Spiel. Gender Stereotypes in education: Development, consequences and interventions. European Journal of Developmental Psychology, 2016. DOI:10.1080/17403629.2016.1193483.

[16] H. M. Lips. Sex and Gender: An Introduction (5th ed.). New York: McGraw-Hill, 2005.

[17] B, Johnson, A. Eagly. Effects of involvement and persuasion. A Meta-analysis. Psychological Bulletin, 106, 290-314, 1989.

[18] M. A. Hogg, G. M. Vaughan Social Psychology. Harlow, England: Pearson, 2013.

[19] A. Bisin, T. Verdier. The Economics of Cultural Transmission and the Dynamics of Preferences. Journal of Economic Theory, 97, 298-319, 2001.

[20] J. Tiedemann Teacher's gender stereotypes as determinants of teacher perceptions in elementary school mathematics. Educational Studies in Mathematics, 50, 49-62, 2002.

[21] M. Hall. Gender Representations in Current EFL Textbooks in Iranian Secondary Schools. Journal of Language Teaching and Research, 5, 253-261, 2014.

[22] T. Ramaci, M. Pellerone, C, Ledda, G. Presti, V. Squatrito, V. Rapisardo. Gender stereotypes in occupational choice: a cross-sectional study on a group of Italian adolescents. Psychology research and behavior management, 10, 109, 2017.

[23] P. Y. Ji, R. T. Lapan, K. Tate. Vocational interests and career efficacy expectations in relation to occupational sex-typing beliefs for eighth grade students. Journal of Career Development, 31 (2), 143-154, 2004.

[24] A. Nilsen. Women in Children's Literature. College English, 32 (8), 918-926, 1971. DOI:10.2307/375631

[25] L. J. Weitzman, D. Rizzo. Biased textbooks: images of males and females in Elementary School textbooks in five subject areas; What you can do about biased textbooks, 1974.

[26] S. Ziogou-Karastergiou, V. Deligianni-Kouimtzi. The stereotype of gender roles in textbooks of primary school. Philologos, 23, 282-295, 1981.

[27] D. Makrinioti. Childhood in Reading Schemes 1834-1919. Athens, Dodoni,1986. 
[28] N. Chardalia, A. Ioannidou. Social gender representations in school coursebooks; Literature review. Athens, 2008 (translation from Greek).

[29] D. Gouvias, C. Alexopoulos. Sexist stereotypes in the language textbooks of the Greek primary school: a multidimensional approach. Gender and Education, 30 (5), 642-666, 2016. DOI: 10.1080/09540253.2016.1237620

[30] M. A. Cejka, A. H. Eagly. Gender-stereotypic images of occupations correspond to the sex segregation of employment. Personality and Social Psychology Bulletin, 25 (4), 413-423, 1999.

[31] C. T. Mart. Encouraging Young Learners to Learn English through Stories. English Language Teaching, 5 (5), 101-106, 2012.

[32] A. Mpratsoli, A. Diamantidou. English for the 4th grade. Pupil's book. Athens: School Book Publishing Organization (OEDB), 2009.

[33] A. Arikan. Age, gender and social class in ELT coursebooks: A critical study. Hacettepe Üniversitesi Eğitim Fakültesi Dergisi, 28 (28), 29-38, 2005.

[34] A. Thompson. Caring in context: Four feminist theories on gender and education. Curriculum Inquiry, 33(1), 9-65, 2003.

[35] E. Kolovou, A. Kraniotou. English E' primary school -English 5th grade, pupil's book. Athens: Ministry of Education, Pedagogical Institute, 2009.

[36] Women in Literacy and Life Assembly. Guidelines for gender-fair use of language, 2002.

[37] C. Livingstone. Role play in language learning. London: Longman, 1986.

[38] M. Zafiri. Teaching English to Sixth Grade Greek Primary School students through culture and through the avoidance of stereotypes and prejudice. Proceedings of INTCESS14International Conference on Education and Social Sciences, 2014.

[39] V. Pliogou, E. Kantartzi, M. Triantafullou. Gender representations in the Primary School coursebooks of Science Direction at the last two Grades of Primary school. Research in Education, 6(1), 140-160, 2017. http://dx.doi.org/10.12681/hjre.11940.

[40] E. Efremidou, E. Zoe-Reppa, F. Frouzaki. English for the 6th grade. Pupil's book. Athens: School Book Publishing Organization (OEDB), 2009.

[41] A. Frederick, F. Folerou. Teachers of Primary School. Athens, Ypsilon, 2004.

[42] S. Ara. Use of songs, rhymes and games in teaching English to young learners in Bangladesh. Dhaka University. Journal of Linguistics, 2(3), 161-172, 2009.

[43] N.T. Millington. Using songs effectively to teach English to young learners. Language Education in Asia, 2(1), 134-141, 2011.

[44] M. Knoll. The Project Method: Its Vocational Education Origin and International Development. Journal of Industrial Teacher Education. 34(3), 59-80, 1997. 